\title{
Jenang Karomah Marketing Strategy and Its Impact on Women's Purchase Intention
}

\author{
Yulia Friyanni \\ State Islamic Institute of Kudus, Indonesia \\ yuliafriyanni@gmail.com
}

\begin{abstract}
Jenang Karomah is a business brand that has been established for 24 years to experience the dynamics of sales ups and downs. It is estimated that there is a link between variables of marketing strategy and service quality, especially for women buyers. This variable encourages researchers to research more about marketing strategies which include product, price, place, promotion. This study aims to analyze the marketing strategy of Jenang Karomah in Kudus and their impact on women's buying interest. The research method used in this study is a qualitative method, namely observation and interviews as data collection techniques. The results found four strategies developed by Jenang Karomah. First, the product strategy; packing with a good color, shape and brand, although still found packaging that is less tidy or defective. Second, place strategy; Jenang Karomah is located near the Kudus City Center where the majority of the community are also jenang sellers which results in competition to attract women buyers. Third, pricing strategies; Jenang Karomah fluctuates prices, especially during the moments of the big day before Lebaran or celebration which results in women's buying interest becoming very selective. Fourth, promotion strategies; Jenang Karomah has done offline promotions, but lacks promotion based on internet technology, namely social media such as YouTube, Instagram, Facebook, and Twitter which are widely used by young women as potential buyers. Four strategies developed by Jenang Karomah have influenced women's buying interest in Kudus City. The research method used in this study is qualitative with a descriptive analytical approach.
\end{abstract}

\author{
Keywords \\ credit; banking \\ mediation; covid-19
}

\section{Introduction}

Nowadays in modern era, business actors are faced with conditions of increasing competition. They are required to be more creative and innovative in offering something that is added value compared to what is done by their competitors. Business actors are demanded to be active in the implementation of development, especially through economic activities. Because business actors can provide services to meet the diverse needs of society, both service needs and product needs.

Jenang Karomah is one of the Micro, Small and Medium Enterprises (MSME) in Indonesia, it is located in Kudus Regency. The products offered by Jenang Karomah vary widely, from taste to shape. These products are processed products from home industry that have been running for 24 years. The products produced by Jenang Karomah are well known by the public not only in Kudus Regency, but also in various other areas in Indonesia, such as Jakarta, Batam, Lombok, and others (Arifin, 2019), as well as the distribution areas for these products. Jenang Karamah is famous for its distinctive taste and economical price. It is not only an advantage for Jenang Karomah products, but also the 
commitment of the producers in determining the success of a product that can be accepted by the community.

There are many factors that encourage and influence people in buying a product. They are factors of needing, packaging, pricing and timing of consumption are taken into consideration. This is an important task for Jenang Karomah management in marketing its products. The right marketing strategy can make Jenang Karomah achieve its goals which ultimately lead to the successful sale of a product that is marketed to the public. Seeing the great potential that exists in Indonesia, especially in Kudus Regency, makes MSME players like Jenang Karomah needs to look to develop their businesses and encourage women consumers to be more interested in buying Jenang Karomah products. Moreover, the women are quite important market, as well as financial control holders in the family.

The role of women as mothers, children, and grandchildren in the family requires them to be able to think intelligently in choosing and consuming products. Therefore, Chaesfa and Panjaitan stated that women are big decision makers in fulfilling their household needs (Chaesfa and Panjaitan, 2013). Galvin et al also argued that this behaviour is determined by a socialization process in which personal individuals are shaped by existing cultures and values to be more expressive, sympathetic, nurturing, cooperative, independent, and happy to help. This also causes women to care about their surroundings.

The responsibility that is owned by women to take care of the household, take care for children and families, directs them to become people who care about environmental threats to their health and safety. Siti Khoriyah stated that what women do is a characteristic of green consumers. This can be viewed from demographic factors, namely adult women who are married, have children, are highly educated and have regular income (Siti Khoiriyah, 2011). This then develops in an attitude in which women have higher consistency than men because women are more concerned with the effect of their actions on others (Slameto, 2010). These considerations are important in attracting consumers, especially women.

Strategy is a very important role in achieving business success. Not only strategy plays an important role in the survival of the business, but business actors must also pay attention to customer satisfaction after making a relationship with Jenang Karamah. This will later have an impact on consumer loyalty to Jenang Karamah. Customer satisfaction has a close relationship with business in the long term, such a relationship is intended so that business actors can understand and understand consumer needs, and in the end, consumer satisfaction will create consumer loyalty and loyalty to Jenang Karomah which provides good needs and services. good. The strategy carried out by Jenang Karomah will have an impact on people's decisions in buying the products offered.

Seeing this, Jenang Karamah's attention should no longer be limited to the product (goods or services produced), but also to the aspects of the process, human resources, and the environment. Only truly qualified MSMEs can win the competition in their market. If the quality of service produced is superior, it will encourage a large market share. So, marketing strategy and company quality are closely related. MSMEs that offer superior quality goods or services will be able to beat competitors whose service quality is inferior.

Parasuraman, Zeithaml, and Berry in Tjiptono and Chandra managed to identify five main dimensions in service quality, namely: reliability, responsiveness, assurance, empathy, tangibles. There are several studies on marketing mix strategies that have been carried out, pointing to different results (2011: 196).

A research conducted by Chandra, Sitompul, and Matondang (2014) shows that indicators of product marketing strategies and prices have a strong and balanced influence 
on customer purchases. In research on service quality put forward by Ferdiansyah, Darta, and Anggarawati (2014) it shows that service quality has a positive and significant effect on customer loyalty which has an impact on purchasing decisions. Taking into account the description of the research, the researcher conducted a study entitled "Jenang Karomah Marketing Strategy and Its Impact on the Interests of Women Buyers". This study has a difference from previous research, namely this study looks from two perspectives of the variable dimensions of the Marketing Strategy dimension and the dimension of women buyers' interest variables. These two variables have indicators that can be linked to one another, so that it can be seen that the significant impact made on the Jenang Karomah Marketing Strategy on the Interests of Women Buyers can be seen.

\section{Review of Litrature}

\subsection{Strategy}

Hamel and Prahalad explained that a strategy is an action that is incremental (always increasing) and is continuously carried out based on the point of view of what consumers expect in the future. In addition, Richard L. Daft also argues that strategy is an activity plan that describes the allocation of resources to face the environment, gain competitive advantage, and achieve company goals. The competitive advantage itself is something that differentiates one company from another and gives the company characteristics to meet consumer needs, in this case the Jenang Karomah shop with other Jenang stores.

Strategy is a plan or step made by the decision-maker to achieve the desired goals or solve a problem through formulations of solving for short-term or long-term. A strategy contains tips, ways, and tactics prepared systematically and comprehensively to achieve the goals and consist of the ways to create effective relations between organizational resources with the environment both inside and outside the organization. (Suprayitno et al, 2019)

Mintzberg, as quoted by Ismail Sholihin stated that the concept of strategy must be seen from various dimensions, so Mintzberg called it a "5 P Strategy" including:

a. Plan Strategy (Plan)

This planning strategy has two characteristics, namely the first is a plan that is deliberately and consciously made. While the second is a plan that is developed in order to achieve a goal

b. Maneuvering Strategy (Play)

This strategy poses a threat to the company's competitors.

c. Pattern Strategy (Pattern)

This strategy shows that a series of activities carried out by management in pursuit of a goal.

d. Positioning Strategy (Position)

This positioning strategy shows the various decisions the company has chosen to provide the right position in the corporate environment.

e. Point of View Strategy (Perspective)

This point of view strategy shows that strategic decision makers view their world to be shared values in an organization.

\subsection{Marketing}

Marketing can be defined as the result of business activities that drive goods and services from producers to consumers, and include buying, selling, transportation, warehousing, financing, and risking. The American Marketing Association (AMA) defines 
that marketing as the planning and implementation process of pricing, promotion, goods and services to create exchanges that satisfy individual and organizational goals (Anoraga Pandji, 2007).

Marketing is very influential on the development of goods and services, marketing activities consisting of pricing, promotion and distribution to meet consumer needs. Besides that, it also has an important role in society, including in the economic and social fields.

It has several types including branding, broadcast advertising, multi-level marketing, internet or online. In addition to types, marketing also has a function, namely the first is marketing as a product introduction, with the introduction of this product, the marketing party must highlight the product being marketed. The second is the function of marketing as research so that consumers get the right information about the products being marketed. The third is marketing as distribution, ensuring that the products marketed are easy for consumers to get. Fourth, marketing as an after-sale service means that the marketing party must assist consumers in buying products.

\subsection{Marketing Strategy}

Marketing strategy is basically a comprehensive plan, integrated and in the field of marketing, which provides guidance on the activities to be carried out in order to achieve the marketing objectives of a company (Assauri Sofjan, 2007). This marketing strategy will not work if the strategy is not used properly. So, the marketing strategy itself is a plan that is in line in the marketing field to get maximum results. The marketing strategy can be said to be successful if every consumer is satisfied with the products offered at the company.

Marketing is a process of planning and execution, starting from the conception stage, pricing, promotion, to the distribution of goods, ideas and services, to make exchanges that satisfy the individual and his institutions. (Kasali in Dianto et al, 2020)

In the marketing strategy management application there is a side that must be considered, namely culture. It turns out, so far, many large companies have made culture an important record in the creation and marketing of their products. In terms of color alone can be one of the factors causing consumer purchasing behavior decisions (Fahmi Irham, 2014).

\subsection{The Interest of Women Buyers}

The instinct of a woman whose hobby is shopping has turned out to be the right target for entrepreneurs. The reason is, most people who have an interest in buying goods and food are women. Therefore, entrepreneurs are competing with each other to promote their respective products. Usually women have a character that relies more on feelings which make them more consumptive in terms of shopping for products. On the other hand, women really like the existence of promotional strategies such as discount promotions, free promotions, voucher promotions, gift promotions, and the promotional packages that can be exemplified buy 2 free 1 . Therefore, a potential target market is women.

Maulana and Kurniawati explained that the interest of women buyers is an activity of a learning process and a thought process regarding perceptions that arise in creating a motivation that is stored in the mind, and makes it an activity that requires women to realize their desire to buy. 


\section{Research Methods}

The research method used by researchers is qualitative with a descriptive analytical approach, where qualitative research is research based on the opinions of participants so that researchers try to build meaning about a phenomenon or event based on the views of the participants. In this case the researcher identifies a culture sharing community, then examines how the community develops behavior patterns at different times (Creswell John W, 2016). The sources of data are in this study obtained by observation and interviews. Researchers conducted research using the observation method because observation is an activity of recording phenomena systematically, in addition to using the observation method the researcher also uses the interview method because the interview is one of the data collection techniques by meeting and asking directly to shop owners, as well as with consumers, especially women consumers so that Researchers know about the marketing strategies contained in Jenang Karomah and how interested are women buyers in these stores.

\section{Results and Discussion}

\subsection{The history of Jenang Karomah}

Jenang Karomah is a branch of the "Muria" jenang which was founded by Mr. Dahwan (late) and Mrs. Mastuni (late) who are the parents of the owner of Jenang Karomah in 1973. Dahwan established a jenang business because jenang is a traditional food that is loved by many, both parents, teenagers and even children. Apart from these reasons, in the Kudus City there are two religious tourism sites, namely the Sunan Muria Tomb and the Sunan Kudus Tomb, so many pilgrims visit them, especially those who come from outside the city. This reason is a logical factor because when visitors return to their city, they can bring souvenirs from the Kudus City. Jenang is a typical food and is much in demand by visitors to be used as souvenirs. Another reason that encourages Dahwan to set up a jenang business is the public's request for jenang to be used as luggage when applying. Cultural and mythological factors that develop in society are also the reasons for themselves, namely the sticky contours of the jenang have a deep philosophical meaning. Sticky rice can tighten people who are getting married. These reasons motivated Dahwan to establish a jenang business which his children later continued.

After Dahwan's death, the jenang business was continued by Zaenal Arifin and his two siblings. Zaenal changed the name Jenang Muria to Jenang Karamah. This is because the Jenang Muria brand has been used by the two Zaenal brothers. Therefore, Jenang Karamah was chosen to distinguish it from Jenang Muria. Zaenal was accompanied by his wife, Masfuah Enti Aliyah. Since 1995, Zaenal and his wife have developed Jenang Karomah. Starting from two employees, the business Zaenal has developed has now massproduced and sold jenangs in various regions.

Zaenal's children, namely Ahmad Zahroni Fuad, Ahmad Latif Arsyad, Ahmad Nuril Karim, and Syarifah Sya'adati participated in developing the Jenang Kromah business. The division of roles began to be tidier. 2 male employees serve as Jenang cooks, and two women are in charge of packaging, while Zaenal and his wife and children are in charge of marketing and promoting their jenang products (Arifin, 2019).

Along with time, Jenang Karomah employees are increasing now. The job description is more complete. There are 7 employees in the production and warehouse departments, all of whom are men. Meanwhile, in the packaging section, there are 7 women. For the marketing department, there are 6 employees, of which 3 people work in 
the morning, and 3 others work at night. The development of Jenang Karamah has gradually begun to take shape. Not only that, the involvement of Jenang Karomah in various local and international events has encouraged Jenang Karomah management to further strengthen its business building.

The real involvement carried out by Jenang Karomah began in 2000. Jenang Karomah was involved independently in the exhibition at the Jam'iyyatul Hujjaj Kudus (JHK) building. With this exhibition he has made Jenang Karomah products known by many government and private agencies, especially the agricultural agency. As a result, the related agencies encouraged Jenang Karomah to be actively involved in various, especially the national event held in Tasikmalaya in 2002. Since then, Jenang Karomah has been continuously involved in various exhibition events held by related agencies throughout Indonesia. This is because the government through the agriculture service wants to introduce and develop jenang as one of the characteristics of the Kudus City.

Zaenal well developed its jenang products. He is also one of the figures who plays an active role in making Kaliputu a jenang tourism industry area. Together with related agencies and agencies, Kaliputu is currently one of the destinations for tourists who want to get a variety of souvenirs typical of Kudus.

Due to the various involvement of Zaenal and Jenang Karomah in various events, Zaenal has managed to get awards. These awards include the 2014 Central Java Food Security Award, the 2014 National Food Security Holder Award, the Kudus Regent Award for dedication in the field of development of the traditional snacks industry 2010, the 2005 Kudus district award for the winner of the Nomination Competition for the Success of Development and K3 Suci in the Gebyar Pesona event. Tourism 1 of 2007 from the Association of Tourism Actors for the City of Semarang and Central Java, the 2005 Agro \& Food Expo Award with 1st place in the arrangement of stands by UMK, Certificate of Home Industry Food Production (SPP-IRT) from the Kudus Regency Health Office 2004, halal certificate from the Institute Assessment of Food, Drugs and Cosmetics, Indonesian Ulema Council, Central Java Province 2013, and a certificate from the Central Java Industry and Trade Service for Acceptance of Jenang Karomah in the 2008 BKDT Nominal Labeling and Quantity System.

Today, Jenang Karomah has developed and has many flavors, including original flavors, durian, peanuts, green beans, black sticky rice, milk chocolate, sesame mocca, strawberry melon, mongso honey and many other flavors. These products are sold at the Jenang Karomah shop, Jl. Sosrokartono 263 Rt 01/02 Kaliputu Kudus, a village located in Kecamatan Kota Kudus Regency, with a population of 3,204 people, consisting of 1596 men and 1,608 women. Kaliputu has an area of 54.31 ha, consisting of 18 neighborhood associations (RT), 3 community associations (RW) and 2 hamlets, namely Kaliputu and Gedangan.

\subsection{Production and Packaging Concept (Packing)}

Jenang Karomah produces 1 quintal of flour a day. The process is done in a semimodern way. Stirring the jenang using a machine with the help of human power to control the dough. The dough is stirred until it has a sufficient level of maturity, until finally it is cooled and then packing is carried out.

In the packing section, there are two processes, namely the jenang cutting process or better known as the title process and the packaging process. Jenang is packed in small plastic, after which it is put in mica and plastic measuring half a kilogram and one kilogram or put in various shapes and sizes that have been provided. After being put in the packaging, the processed jenang is labeled or the Jenang Karomah brand and adjusted to 
the taste of the jenang. So, the packaging label has included a feeling of jenang, in addition to information about product expiration (expired product) under the mica packaging in order to make it easier for consumers, especially female consumers who will be observant of the jelly.

\subsection{Marketing Strategy Concept}

A promotion is an activity that must be carried out by a business to introduce its products to consumers, especially female consumers and is one of the keys to success that can make products that are made in demand by the community and the business that they run can be successful. Promotional activities carried out, namely by making videos that introduce products sold in Jenang Karomah in the form of Jenang with many flavors such as green beans, black sticky rice, original, cocholate milk, and so on so that consumers, especially female consumers, are very interested and can choose their own variants. taste of Jenang Karamah. Then after making the video, jenang karomah promotes its products with the E Commerce program which means the sale and purchase of goods and services through electronic systems such as the internet or television, websites, or other computer networks. This e-commerce activity is an application and application of e-business (ebusiness) related to commercial transactions. In addition, Jenang Karomah is promoting with online shops such as, Tokopedia, Bukalapak, Instagram, and Shopee to collaborate with the aim of making Jenang Karomah expand its marketing reach. Besides that, Jenang Karomah can also sell its products through resellers or entrust them to minimarkets or supermarkets. Currently, Jenang Kudus Karomah continues to grow with very fast progress. Apart from continuing to innovate the latest products, the company is also modernizing the process of making Jenangs.

Obviously, all Karamah products are made with original ingredients, not essence. So that the taste and aroma is very delicious and delicious, different from the others. Karomah is a pioneer of Jenang's product for a long time, making food durability with the basic ingredients of sticky rice, coconut, granulated sugar and coconut sugar for a long period of time up to a matter of months.

\section{Conclusion}

Jenang is one of the typical foods that come from the Kudus City. Jenang Karomah makes jenang a mainstay product that can be enjoyed by the wider community. Jenang Karomah is in the village of Kaliputu, near the City Center of Kudus, where the majority of the people are jenang sellers. This results in competition in order to attract buyers, especially women. Even so, Jenang Karomah remains one of the shops that is in great demand by female consumers because Jenang Karomah carries out a strategy in marketing its products. The marketing strategies developed by Jenang Karomah are first, product strategy; do the packaging in a good color, shape and brand, even though the packaging is not neat or defective. Second, the place strategy; Jenang Karomah is located near the City Center of Kudus where the majority of the people are also jenang sellers which results in competition to attract female buyers. Third, the pricing strategy; Jenang Karomah conducts price fluctuations, especially during the moments of the big day before Eid or celebration which results in women's buying interest being very selective. Fourth, promotion strategy; Jenang Karomah has carried out offline promotions, but lacks promotion based on internet technology, namely social media such as YouTube, Instagram, Facebook and Twitter which are widely used by young women as potential buyers. The four strategies developed by Jenang Karomah have influenced women's buying interest in Kudus City. 


\section{References}

Anoraga Pandji. (2007). Pengantar Bisnis. Jakarta: PT Rineka Cipta.

Assauri Sofjan. (2007). Manajemen Pemasaran. Jakarta: PT Raja Grafindo.

Creswell John W. (2016). Research Design (4th ed.). Yogyakarta: Pustaka Pelajar.

Dianto, E. et al. (2020). BNI Marketing Strategy for Credit Cards in Dealing Global Competition in State Bank Indonesia (Persero) Tbk Banda Aceh Branch Office. Budapest International Research and Critics Institute-Journal (BIRCI-Journal). 11341146

Fahmi Irham. (2014). Manajemen Strategis. Bandung: ALFABETA.

Kotler, P. and G. Armstrong. (2004). Dasar-dasar Pemasaran, Edisi Kesembilan. Jakarta:Penerbit Indeks

Kotler, P. (2005). Manajemen Pemasaran. Jakarta:Indeks Media Group

Purwanto, I. (2008). Manajemen Strategi. Bandung:CV Ryama

Suprayitno et al. (2019). Strategy on the National Unity and Politics Agency (KESBANGPOL) in Maintaining Ethnicity and Religious Relations Based on Huma Betang Philosophy in Central Kalimantan. Budapest International Research and Critics Institute-Journal (BIRCI-Journal). P. 229-238

Tjiptono, Fandy. (2008). Strategi Pemasaran Edisi III. Yogyakarta:CV. Andi Offset

Widya Setiadi, Nugroho J. (2003). Perilaku Konsumen: Konsep dan Implikasi untuk Strategi dan Penelitian Pemasaran. Jakarta: Kencana 